\title{
Foundation Lecturer's Performance Antecedents (Empirical Study on Private Universities in Medan)
}

\author{
Kuras Purba \\ Doctoral Program, Faculty of Economic and Business, \\ University of Sumatera Utara \\ Medan, Indonesia \\ kuraspurba@yahoo.co.id \\ Elisabeth Siahaan \\ Doctoral Program, Faculty of Economic and Business, \\ University of Sumatera Utara \\ Medan, Indonesia \\ dr.elisabethsiahaan@yahoo.com
}

\author{
Prihatin Lumbanraja \\ Doctoral Program, Faculty of Economic and Business, \\ University of Sumatera Utara \\ Medan, Indonesia \\ titienlbnraja@yahoo.com \\ Parapat Gultom \\ Doctoral Program, Faculty of Economic and Business, \\ University of Sumatera Utara \\ Medan, Indonesia \\ par_gultom@yahoo.com
}

\begin{abstract}
This study aims to examine empirically the antecedents of foundation lecturer's performance. There are four variables measured which consists of foundation management, university governance, dean's leadership and lecturer's performance. Data analysis is based on 576 students of nine universities in Medan using the Structural Equation Modeling assisted with an application of SmartPls. The model is acceptable and successfully proves a significant influence of hypothesis: 1 . Foundation management has positive and significant impact on university governance; 2 . Foundation management has directly positive and significant impact on dean's leadership; 3 . Foundation management has positive and significant impact on lecturer's performance; 4. University management has positive and significant impact on dean's leadership; 5. University governance has positive and significant impact on lecturers' performance; 6. Dean leadership has positive and significant influence on lecturer's performance; 7. Foundation management has positive and significant impact on dean's leadership through university governance; 8. Foundation management has positive and significant impact on lecturer's performance through university governance; 9. Foundation management has positive and significant impact on the performance of lecturers through dean's leadership, and 10. University governance has positive and significant impact on lecturers' performance through the leadership of the dean
\end{abstract}

Keywords-lecturer's performance; university governance; dean's leadership; foundation management

\section{INTRODUCTION}

This The competition of higher education graduates in Indonesia is getting increased due to the implementation of ASEAN Economic Community (AEC). Responding to the importance of quality improvement of universities, it is necessary to make improvements and development of qualified education in order to compete and able to graduate high competent students. The competency standards of state and private university graduates are essential to produce a competitive Indonesian workforce. Improving the quality of education is one of the government's commitments in the education sector [1]. The accreditation system of study programs conducted by the National Accreditation Board (BAN) focuses on the supervision of universities to produce quality education for students. The graduation criteria of a study program are formulated in the form of Graduate Competency Standards contained in the curriculum design [2]. National Standards of Education states that "Graduate Competency Standards" is a qualification of graduate competencies covering attitude, knowledge, and skills. The government has launched a curriculum based on the Indonesian National Qualification Framework (KKNI). The KKNI curriculum contains the competencies of courses consisting of cognitive, psychomotor, and affective or attitudes. KKNI is a framework of work qualification gap that juxtaposes, equalize, integrate, the education and training sector and work experience in the framework of giving the recognition of work competence in accordance with job positions in various sectors.

The role of lecturer is very important in order to yield the qualified graduates. Higher education institution (HEI) that has qualified lecturers will be much in demand by the community at this time and in the future [3]. HIE that does not want to keep up with current and future changes will be abandoned by the community and slowly or quickly will suffer a setback, which will eventually end up with an HEI dismissal. In addition, HEI should have good governance, because governance focuses on the control and oversight of organizational structure, duties, personnel functions, governance and leadership mechanisms. Governance which is implemented properly in accordance with established rules will encourage lecturers to work professionally because the organizational structure, tasks, functions of personnel and mechanisms are clearly applied and management leadership in favor of the teaching staff. On top of that, the foundation role of private HEI is the main factor in developing HEI. The number of private HEIs in Indonesia is much higher with public HEIs. Thus the improvement of university governance of private HEIs is so important in order to yield qualified and competitive graduates. 
This study aims to investigate factors which influence lecturer's performance and its impact on student's competency. The factors are studied including foundation management, university governance, dean leadership, and environment study.

\section{LITERATURE REVIEW}

According to Indonesia Act No. 16 Year 2001, Foundation is a legal entity consisting of wealth separated and designated to achieve certain goals in the social, religious, and humanitarian fields, which do not have members.

Deans as academic leaders exercise their leadership within settings that have markedly different institutional purposes, cultures, and expectations than the organizations in which business leaders typically exercise their leadership [4]. Leadership operates within the framework of purpose: vision, shared values, and common cause. The leader does not have to create the vision, but there must be one, and it must be shared by others who willingly commit themselves in common cause.

Effective academic leadership needs to utilize communication skills, organizational culture and shared values in order to fulfill mutual trust [5]. Consequently, the interests of faculties, staffs, and leaders converge toward common organizational aims. Leaders should not only direct reciprocal communication but also provide an effective communication network inside and outside universities. Mutual trust and respect provide an appropriate context and move the organization toward individual and collective goal attainments. Academic leadership should be transformational and collaborative, emphasizing participation, delegation, and teamwork. Driven by the dynamic nature of the academic environment, recommendations for acceptable management based upon an increased utilization of teams and workgroups with multidisciplinary collaboration at local, regional, and international levels should offer a decreased reliance on traditional authority arrangements [6]. There are three activities deans must perform to lead effectively: building a community of scholars; setting direction; and empowering others. Overall, deans were found to be balanced in their approaches to leadership, with deans in comprehensive universities more likely to describe themselves as community builders than deans in research universities. It was further revealed that after about year 10, deans tend to disengage in direction setting behavior, a finding that may have implications for institutional development.

\section{METHODOLOGY}

\section{A. Sampling of Research and Data Collection}

The population of this study is active students of Management Studies Program, in the last semester at a private university in Medan City, North Sumatra Province. Based on these criteria, the population of 576 people is obtained from 9 private universities. The selection of the private universities is based on the university that the number of students graduates from year to year in the last three years increases.

The number of sample in this research is calculated based on the total number of indicators times 6 , so the number of samples is $6 \times 96=576$ students [7]. Number of sample in each university is selected using proportional random sampling. Data of this research are collected using three methods: (1) documentation desk, (2) questionnaires, and (3) interview with key persons in university.

This research consists of 4 (four) constructs, namely Foundation Management, University Governance, Dean Leadership, and Lecturer Performance. Foundation management is reflected by planning, organizing, actuating, and controlling. University governance is reflected in eight dimensions: Transparency, Accountability, Responsibility, Independence, Justice, Relevance, Effectiveness and Efficiency, and Nonprofit. Dean's leadership is reflected by seven dimensions: Level of clarity of vision and mission, Level of achievement of vision and mission, Level of Optimism, Level of Confidence, Level of Speed of Action, Level of Willpower, level of willingness in Delegating Authority. Lecturer's performance is significantly reflected by Education and Teaching, Research and science development, Community Service.

\section{B. Hypothesis}

This research consists of ten hypotheses to be proved, i.e.:

H1: Foundation management has positive impact on university governance;

$\mathrm{H} 2$ : Foundation management has direct positive impact on dean's leadership;

H3: Foundation management has positive and significant impact on lecturer's performance;

H4: University management has positive impact on dean's leadership;

H5: University governance has positive impact on lecturers' performance;

H6: Dean leadership has positive influence on lecturer's performance;

H7: Foundation management has a positive impact on dean's leadership through university governance;

H8: Foundation management has a positive impact on lecturer's performance through university governance;

H9: Foundation management has positive impact on the performance of lecturers through dean's leadership.

H10: University governance has positive impact on lecturers' performance through the leadership of the dean

\section{RESULTS}

\section{A. Characteristic of the Respondents}

The composition of respondents by sex and status of work is shown in Table 1. 
Table 1: Composition of respondents by sex and status

\begin{tabular}{|l|c|c|c|c|c|}
\hline \multirow{2}{*}{ Sex } & \multicolumn{4}{|c|}{ Status of Work } & \multirow{2}{*}{ Total } \\
\cline { 2 - 6 } & $\begin{array}{c}\text { Full } \\
\text { Time }\end{array}$ & $\begin{array}{c}\text { Part } \\
\text { Time }\end{array}$ & Internship & $\begin{array}{c}\text { Not } \\
\text { Working }\end{array}$ & \\
\hline Male & 22 & 24 & 26 & 178 & 250 \\
\hline Female & 14 & 23 & 7 & 282 & 326 \\
\hline Total & 36 & 47 & 33 & 460 & 576 \\
\hline
\end{tabular}

From the calculation results, it is obtained value of $\mathrm{P}$-value $=$ $0.01105<0.05$, it can be concluded that there are differences in working status between male students and female students.

Characteristics of respondents by sex and activeness in the organization of 9 (nine) private universities in the city of Medan are shown in Table 2.

Table 2: Composition of Respondents by Sex and Activeness in the Organization

\begin{tabular}{|l|r|r|r|r|}
\hline \multirow{2}{*}{ Sex } & \multicolumn{2}{|c|}{ Activeness in the Organization } & \multirow{2}{*}{ Total } \\
\cline { 2 - 4 } & $\begin{array}{c}\text { Still } \\
\text { Active }\end{array}$ & $\begin{array}{c}\text { Never } \\
\text { Active }\end{array}$ & $\begin{array}{c}\text { Not } \\
\text { Active }\end{array}$ & \\
\hline Male & 58 & 86 & 106 & 250 \\
\hline Female & 89 & 87 & 150 & 326 \\
\hline Total & 147 & 173 & 256 & 576 \\
\hline
\end{tabular}

From the calculation results in Table 5.11 obtained value of $\mathrm{P}$ value $=0.1717>0.05$, it can be concluded that there is no difference in working status between male students and female students. That is both men and women the same level of activity in organizing on campus. This conclusion denies the allegation that women are less active in organizing on campus than men.

\section{B. Responses of Respondents on Variables}

Responses of respondents on all variables in this research are shown in Table 3.

The results show that the foundation management has the highest value on planning and the lowest value actuating. This means that foundation is most focus their role in planning but due to weak of actuating, then the achievement of the university target is not totally obtained. Meanwhile, the university governance has the highest on accountability and the lowest value on independency and nonprofit. It means that the university managers mostly are not independent on managing the university, the foundation does intervention on university managing. Similarly, university managers do not manage the university as a non-profit organization.

Dean leadership has the strongest on clarity of vision and mission. It means that deans mostly reflect the vision and mission of university into the vision and mission of faculty. However, the deans have the lowest value on the willingness level of delegate (authority). It means that most of the deans do not want to distribute and delegate their works/tasks to other staffs. This condition causes many tasks cannot be finished on time. From lecturer perspective, it shows that lecturer has strong in the area of education and teaching but still weak in area of research and science development. It means that many lecturers do not do research and the research results are not highly good quality. It causes many lecturers do not write their research result in high reputation academic journal.

Table 3: Responses of Respondents

\begin{tabular}{|c|c|c|c|}
\hline Variable & Dimension & Mean & Category \\
\hline \multirow{5}{*}{$\begin{array}{l}\text { Foundation } \\
\text { Management }\end{array}$} & & 3.86 & Good \\
\hline & Planning & 4.01 & Good \\
\hline & Organizing & 3.85 & Good \\
\hline & Actuating & 3.71 & Good \\
\hline & Supervision & 3.87 & Good \\
\hline \multirow{9}{*}{$\begin{array}{l}\text { University } \\
\text { Governance }\end{array}$} & & 3.89 & Good \\
\hline & Transparency & 3.76 & Good \\
\hline & Accountability & 4.12 & Good \\
\hline & Responsible & 3.94 & Good \\
\hline & Independence & 3.72 & Good \\
\hline & Justice & 3.92 & Good \\
\hline & Relevance & 3.93 & Good \\
\hline & Effectiveness and Efficiency & 3.99 & Good \\
\hline & Nonprofit & 3.72 & Good \\
\hline \multirow{8}{*}{$\begin{array}{l}\text { Dean } \\
\text { Leadership }\end{array}$} & & 3.77 & Good \\
\hline & Clarity of Vision and Mission & 3.84 & Good \\
\hline & Level of Vision and Mission Achievement & 3.75 & Good \\
\hline & Level of Optimism & 3.83 & Good \\
\hline & Level of Confidence & 3.79 & Good \\
\hline & Speed Level of Action & 3.76 & Good \\
\hline & The Will of Giving an Example & 3.73 & Good \\
\hline & Willingness Level Delegates (Authority) & 3.7 & Good \\
\hline \multirow{4}{*}{$\begin{array}{l}\text { Lecturer } \\
\text { Performance }\end{array}$} & & 3.73 & Good \\
\hline & Education and Teaching & 3.8 & Good \\
\hline & Research and Science Development & 3.7 & Good \\
\hline & Community service & 3.73 & Good \\
\hline
\end{tabular}

\section{The Model of The Research}

The direct effect among variables in Table 4. 
Table 4: Direct Effects of Among Variables

\begin{tabular}{|l|r|r|}
\hline & $\begin{array}{c}\text { Original } \\
\text { Sample }\end{array}$ & $\begin{array}{c}\text { P } \\
\text { Values }\end{array}$ \\
\hline DEAN LEADERSHIP -> Action Taking Level & 0.895 & 0.000 \\
\hline DEAN LEADERSHIP -> Authority Delegation Level & 0.888 & 0.000 \\
\hline DEAN LEADERSHIP -> Confidence Level & 0.905 & 0.000 \\
\hline DEAN LEADERSHIP -> Lecturer Performance & 0.087 & 0.014 \\
\hline DEAN LEADERSHIP -> Optimism Level & 0.906 & 0.000 \\
\hline DEAN LEADERSHIP -> Role Model Willingness & 0.901 & 0.000 \\
\hline DEAN LEADERSHIP -> Vision and Mision Achievement Level & 0.899 & 0.000 \\
\hline DEAN LEADERSHIP -> Vision and Mision Understanding Level & 0.818 & 0.000 \\
\hline FOUNDATION MANAGEMENT -> Controlling & 0.869 & 0.000 \\
\hline FOUNDATION MANAGEMENT -> DEAN LEADERSHIP & 0.026 & 0.653 \\
\hline FOUNDATION MANAGEMENT -> Directing & 0.841 & 0.000 \\
\hline FOUNDATION MANAGEMENT -> Lecturer Performance & 0.307 & 0.000 \\
\hline FOUNDATION MANAGEMENT -> Organizing & 0.844 & 0.000 \\
\hline FOUNDATION MANAGEMENT -> Planning & 0.778 & 0.000 \\
\hline FOUNDATION MANAGEMENT -> University Governance & 0.728 & 0.000 \\
\hline Lecturer Performance -> Community Services & 0.919 & 0.000 \\
\hline Lecturer Performance -> Research and Knowledge Development & 0.914 & 0.000 \\
\hline Lecturer Performance -> Teaching and Learning & 0.820 & 0.000 \\
\hline University Governance -> Accountability & 0.707 & 0.000 \\
\hline University Governance -> DEAN LEADERSHIP & 0.304 & 0.000 \\
\hline University Governance -> Effectivity and Efficiency & 0.838 & 0.000 \\
\hline University Governance -> Fairness & 0.761 & 0.000 \\
\hline University Governance -> Independency & 0.717 & 0.000 \\
\hline University Governance -> Lecturer Performance & 0.353 & 0.000 \\
\hline University Governance -> Non Profit & 0.704 & 0.000 \\
\hline University Governance -> Relevancy & 0.796 & 0.000 \\
\hline University Governance -> Responsibility & 0.814 & 0.000 \\
\hline University Governance -> Transparancy & 0.703 & 0.000 \\
\hline
\end{tabular}

These results show the following:

- The four dimensions include planning, organizing, actuating, and controlling significantly reflect foundation management.

- University governance is significantly reflected by eight dimensions: Transparency, Accountability, Responsibility, Independence, Justice, Relevance, Effectiveness and Efficiency, and Nonprofit.

- Dean's leadership is significantly reflected by seven dimensions: Level of clarity of vision and mission, Level of achievement of vision and mission, Level of Optimism, Level of Confidence, Level of Speed of Action, Level of Willpower, level of willingness in Delegating Authority.

- Lecturer's performance is significantly reflected by Education.

- Foundation management does not directly effect on dean leadership.

- Foundation management directly and significantly effects on lecturer performance.

- Foundation management directly and significantly effects on university governance.

- University governance directly and significantly effects on dean leadership

- Dean leadership directly and significantly effects on lecturer performance.
Indirect effect among variables in this research is summarized as follows:

Table 5: Indirect Effects among Variables

\begin{tabular}{|l|c|c|}
\hline & $\begin{array}{c}\text { Original } \\
\text { Sample }\end{array}$ & $\begin{array}{c}\text { P } \\
\text { Values }\end{array}$ \\
\hline DEAN LEADERSHIP -> Community Services & 0.080 & 0.014 \\
\hline DEAN LEADERSHIP -> Research and Knowledge Development & 0.079 & 0.014 \\
\hline DEAN LEADERSHIP -> Teaching and Learning & 0.071 & 0.018 \\
\hline FOUNDATION MANAGEMENT -> Accountability & 0.515 & 0.000 \\
\hline FOUNDATION MANAGEMENT -> Action Taking Level & 0.222 & 0.000 \\
\hline FOUNDATION MANAGEMENT -> Authority Delegation Level & 0.220 & 0.000 \\
\hline FOUNDATION MANAGEMENT -> Community Services & 0.538 & 0.000 \\
\hline FOUNDATION MANAGEMENT -> Confidence Level & 0.224 & 0.000 \\
\hline FOUNDATION MANAGEMENT -> DEAN LEADERSHIP & 0.221 & 0.000 \\
\hline FOUNDATION MANAGEMENT -> Effectivity and Efficiency & 0.610 & 0.000 \\
\hline FOUNDATION MANAGEMENT -> Fairness & 0.554 & 0.000 \\
\hline FOUNDATION MANAGEMENT -> Independency & 0.522 & 0.000 \\
\hline FOUNDATION MANAGEMENT -> Lecturer Performance & 0.279 & 0.000 \\
\hline FOUNDATION MANAGEMENT -> Non Profit & 0.512 & 0.000 \\
\hline FOUNDATION MANAGEMENT -> Optimism Level & 0.224 & 0.000 \\
\hline FOUNDATION MANAGEMENT -> Relevancy & 0.580 & 0.000 \\
\hline FOUNDATION MANAGEMENT -> Research and Knowledge Development & 0.535 & 0.000 \\
\hline FOUNDATION MANAGEMENT -> Responsibility & 0.593 & 0.000 \\
\hline FOUNDATION MANAGEMENT -> Role Model Willingness & 0.223 & 0.000 \\
\hline FOUNDATION MANAGEMENT -> Teaching and Learning & 0.480 & 0.000 \\
\hline FOUNDATION MANAGEMENT -> Transparancy & 0.512 & 0.000 \\
\hline FOUNDATION MANAGEMENT -> Vision and Mision Achievement Level & 0.223 & 0.000 \\
\hline FOUNDATION MANAGEMENT -> Vision and Mision Understanding Level & 0.203 & 0.000 \\
\hline University Governance -> Action Taking Level & 0.272 & 0.000 \\
\hline University Governance -> Authority Delegation Level & 0.270 & 0.000 \\
\hline University Governance -> Community Services & 0.349 & 0.000 \\
\hline University Governance -> Confidence Level & 0.275 & 0.000 \\
\hline University Governance -> Lecturer Performance & 0.026 & 0.040 \\
\hline University Governance -> Optimism Level & 0.275 & 0.000 \\
\hline University Governance -> Research and Knowledge Development & 0.347 & 0.000 \\
\hline University Governance -> Role Model Willingness & 0.274 & 0.000 \\
\hline University Governance -> Teaching and Learning & 0.2711 & 0.000 \\
\hline University Governance -> Vision and Mision Achievement Level & 0.000 \\
\hline University Governance -> Vision and Mision Understanding Level & 0.000 \\
\hline
\end{tabular}

The result shows the following effects:

- The indirect effect of Foundation Management on dean leadership is significant.

- The indirect effect of Foundation Management on lecturer performance is significant.

- The indirect effect of university governance on lecturer performance is significant.

The total effects among variables are shown in Table 6 . From the results, it can conclude that:

- Foundation management directly effects on dean leadership.

- Foundation management directly and significantly effects on lecturer performance.

- Foundation management directly and significantly effects on university governance.

- University governance directly and significantly effects on dean leadership

- Dean leadership directly and significantly effects on lecturer performance. 
Table 6: Total Effect of Among Variables

\begin{tabular}{|c|c|c|}
\hline & \begin{tabular}{|c|} 
Original \\
Sample \\
\end{tabular} & $\begin{array}{c}\mathrm{P} \\
\text { Values }\end{array}$ \\
\hline DEAN LEADERSHIP -> Action Taking Level & 0.895 & 0.000 \\
\hline DEAN LEADERSHIP -> Authority Delegation Level & 0.888 & 0.000 \\
\hline DEAN LEADERSHIP -> Community Services & 0.080 & 0.014 \\
\hline DEAN LEADERSHIP -> Confidence Level & 0.905 & 0.000 \\
\hline DEAN LEADERSHIP -> Lecturer Performance & 0.087 & 0.014 \\
\hline DEAN LEADERSHIP -> Optimism Level & 0.906 & 0.000 \\
\hline DEAN LEADERSHIP -> Research and Knowledge Development & 0.079 & 0.014 \\
\hline DEAN LEADERSHIP -> Role Model Willingness & 0.901 & 0.000 \\
\hline DEAN LEADERSHIP -> Teaching and Learning & 0.071 & 0.018 \\
\hline DEAN LEADERSHIP -> Vision and Mision Achievement Level & 0.899 & 0.000 \\
\hline DEAN LEADERSHIP -> Vision and Mision Understanding Level & 0.818 & 0.000 \\
\hline FOUNDATION MANAGEMENT -> Accountability & 0.515 & 0.000 \\
\hline FOUNDATION MANAGEMENT -> Action Taking Level & 0.222 & 0.000 \\
\hline FOUNDATION MANAGEMENT -> Authority Delegation Level & 0.220 & 0.000 \\
\hline FOUNDATION MANAGEMENT -> Community Services & 0.538 & 0.000 \\
\hline FOUNDATION MANAGEMENT -> Confidence Level & 0.224 & 0.000 \\
\hline FOUNDATION MANAGEMENT -> Controlling & 0.869 & 0.000 \\
\hline FOUNDATION MANAGEMENT -> DEAN LEADERSHIP & 0.248 & 0.000 \\
\hline FOUNDATION MANAGEMENT -> Directing & 0.841 & 0.000 \\
\hline FOUNDATION MANAGEMENT -> Effectivity and Efficiency & 0.610 & 0.000 \\
\hline FOUNDATION MANAGEMENT -> Fairness & 0.554 & 0.000 \\
\hline FOUNDATION MANAGEMENT -> Independency & 0.522 & 0.000 \\
\hline FOUNDATION MANAGEMENT -> Lecturer Performance & 0.585 & 0.000 \\
\hline FOUNDATION MANAGEMENT -> Non Profit & 0.512 & 0.000 \\
\hline FOUNDATION MANAGEMENT -> Optimism Level & 0.224 & 0.000 \\
\hline FOUNDATION MANAGEMENT -> Organizing & 0.844 & 0.000 \\
\hline FOUNDATION MANAGEMENT -> Planning & 0.778 & 0.000 \\
\hline FOUNDATION MANAGEMENT -> Relevancy & 0.580 & 0.000 \\
\hline FOUNDATION MANAGEMENT -> Research and Knowledge Devo & 0.535 & 0.000 \\
\hline FOUNDATION MANAGEMENT -> Responsibility & 0.593 & 0.000 \\
\hline FOUNDATION MANAGEMENT -> Role Model Willingness & 0.223 & 0.000 \\
\hline FOUNDATION MANAGEMENT -> Teaching and Learning & 0.480 & 0.000 \\
\hline FOUNDATION MANAGEMENT -> Transparancy & 0.512 & 0.000 \\
\hline FOUNDATION MANAGEMENT -> University Governance & 0.728 & 0.000 \\
\hline FOUNDATION MANAGEMENT -> Vision and Mision Achievemer & 0.223 & 0.000 \\
\hline FOUNDATION MANAGEMENT -> Vision and Mision Understandi & 0.203 & 0.000 \\
\hline Lecturer Performance -> Community Services & 0.919 & 0.000 \\
\hline Lecturer Performance -> Research and Knowledge Development & 0.914 & 0.000 \\
\hline Lecturer Performance -> Teaching and Learning & 0.820 & 0.000 \\
\hline University Governance -> Accountability & 0.707 & 0.000 \\
\hline University Governance -> Action Taking Level & 0.272 & 0.000 \\
\hline University Governance -> Authority Delegation Level & 0.270 & 0.000 \\
\hline University Governance -> Community Services & 0.349 & 0.000 \\
\hline University Governance -> Confidence Level & 0.275 & 0.000 \\
\hline University Governance -> DEAN LEADERSHIP & 0.304 & 0.000 \\
\hline University Governance -> Effectivity and Efficiency & 0.838 & 0.000 \\
\hline University Governance -> Fairness & 0.761 & 0.000 \\
\hline University Governance -> Independency & 0.717 & 0.000 \\
\hline University Governance -> Lecturer Performance & 0.380 & 0.000 \\
\hline University Governance -> Non Profit & 0.704 & 0.000 \\
\hline University Governance -> Optimism Level & 0.275 & 0.000 \\
\hline University Governance -> Relevancy & 0.796 & 0.000 \\
\hline University Governance -> Research and Knowledge Development & 0.347 & 0.000 \\
\hline University Governance -> Responsibility & 0.814 & 0.000 \\
\hline University Governance -> Role Model Willingness & 0.274 & 0.000 \\
\hline University Governance -> Teaching and Learning & 0.311 & 0.000 \\
\hline University Governance -> Transparancy & 0.703 & 0.000 \\
\hline University Governance -> Vision and Mision Achievement Level & 0.273 & 0.000 \\
\hline University Governance -> Vision and Mision Understanding Level & 0.249 & 0.000 \\
\hline
\end{tabular}

\section{CONCLUSIONS}

The findings show that four dimensions include planning, organizing, actuating, and controlling significantly reflect to foundation management. University governance is significantly reflected by eight dimensions: Transparency, Accountability, Responsibility, Independence, Justice, Relevance, Effectiveness and Efficiency, and Nonprofit. Dean's leadership is significantly reflected by seven dimensions: Level of clarity of vision and mission, Level of achievement of vision and mission, Level of Optimism, Level of Confidence, Level of Speed of Action, Level of Willpower, level of willingness in Delegating Authority. Lecturer's performance is significantly reflected by Education and Teaching, Research and science development, Community Service.

The model is acceptable and successfully proves a significant influence of hypothesis:

1. Foundation management has a positive and significant impact on university governance;

2. Foundation management has directly positive and significant impact on dean's leadership;

3. Foundation management has a positive and significant impact on lecturer's performance;

4. University management has a positive and significant impact on dean's leadership;

5. University governance has a positive and significant impact on lecturers' performance;

6. Dean leadership has positive and significant influence on lecturer's performance;

7. Foundation management has a positive and significant impact on dean's leadership through university governance;

8. Foundation management has a positive and significant impact on lecturer's performance through university governance;

9. Foundation management has a positive and significant impact on the performance of lecturers through dean's leadership, and

10. University governance has a positive and significant impact on lecturers' performance through the leadership of the dean.

\section{References}

[1] Pujiono, and Made, D.S., 2011, Menciptakan Mutu Perguruan Tinggi (Higher Educations) Berskala Internasional Melalui Strategi Penerapan Tata Kelola Universitas Yang Baik (Good University Governance), AKRUAL 3 (1) (2011).

[2] Tampubolon, D.P., 2001, Perguruan Tinggi Bermutu: Paradigma Baru Manajemen Pendidikan Tinggi Menghadapi Abad ke-21, PT. Gramedia Pustaka UtamaJakarta.

[3] Undang-undang Nomor. 20 Tahun 2003 tentang Sistem Pendidikan Nasional. Jakarta: Eka Jaya.

[4] Undang-undang Nomor. 14 Tahun 2005 tentang Guru dan Dosen. Jakarta: Eka Jaya. 
[5] Chairunnisa, C., 2015, Hubungan Tata Kelola Universitas Dan Profesionalitas Dosen, Dengan Mutu Layanan Pendidikan, Faktor Jurnal Ilmiah Kependidikan Vol. 2 No. 3 Nopember 2015 .

[6] Suryarama, 2009, Peran Yayasan Dalam Pengelolaan Bidang Pendidikan Pada Perguruan Tinggi Swasta, Jurnal Organisasi dan Manajemen, Volume 5, Nomor 1, Maret 2009.
[7] Arikunto, S., 2002, Prosedur Penelitian Suatu Pendekatan Praktik. Jakarta: Rineka Cipta. 